\title{
Macrosomia and ambiguous genitalia: a long overdue answer to the citizens of Frusino
}

\author{
Vasiliki Vasileiou, ${ }^{1}$ Anastasia K. Armeni, ${ }^{2}$ Apostolos L. Pierris, ${ }^{3}$ \\ Neoklis A. Georgopoulos ${ }^{2}$
}

${ }^{1} 1^{\text {st }}$ Department of Endocrinology, Diabetes Centre, "Alexandra" Hospital, Athens, ${ }^{2}$ Division of Reproductive Endocrinology, Department of Obstetrics and Gynecology, University of Patras Medical School, Patras, ${ }^{3}$ Philosopher, Director, Institute for Philosophical Research, Patras

\begin{abstract}
In the literature of the Roman Era, a case of macrosomia and genital ambiguity in a newborn is described. Textual evidence concerning this case of androgynism and its symbolism is provided in the present study. Medical interpretation of such cases covers the entire spectrum of differential diagnosis of macrosomia concurrent with genital ambiguity. Female pseudohermaphroditism may be excluded from the differential diagnosis, as the adrenal cortex physiology of the female fetus renders the concurrence of overgrowth and androgen excess unlikely. It will therefore have been a case of $46 \mathrm{XY}$ disorder of sexual differentiation due to either fetal overgrowth syndromes (Beckwith-Wiedemann and Simpson-Golabi-Behmel syndromes) or to mutations of the WT1 gene. Mutations of the WT1 gene are considered as the most probable diagnosis, resulting in genital ambiguity and macrosomia due to additional altered insulin-like growth factor I (IGF-I) and IGF-II action.
\end{abstract}

Key words: Macrosomia, Ambiguous genitalia, Fetal overgrowth syndromes, Wiedemann syndrome, Simpson-Golabi-Behmel syndrome, Wilms Tumor 1 syndromes, Roman history, Titus Livius (Livy)

\section{Address for correspondence:}

Neoklis A. Georgopoulos: Department of Obstetrics and Gynecology, Division of Reproductive Endocrinology, University of Patras Medical School, Rio-26500, Greece, Tel: 2610-999835, Fax: 2610-993854, e-mail: neoklisg@hol.gr Apostolos L. Pierris: Philosopher, Director, Institute for Philosophical Research, Kolokotroni 42, Patras 26221, Greece, www.philosophical-research.org, Tel: 2610-241068, Fax: 2610-271269, e-mail: pierrisapost@hotmail.com ; a.l.pierris@philosophical-research.org

Received 12-12-11, Revised 04-02-12, Accepted 29-02-12

\section{A. AN EXTRAORDINARY BIRTH IN THE CONTEXT OF SIMILAR ROMAN-ERA PRODIGIES}

The Romans are well known to have entertained a particularly intense curiosity mingled with fear as concerns abnormal and unnatural events, one prime example being hermaphrodite newborns. They considered such mishaps, prodigies and monstrosities as full of religious significance, as signs betoken- 
ing an unhealthy state of affairs in the Empire, as manifestations of divine displeasure and as omens of imminent or future adversity. In the event of their arising, elaborate rituals were enacted as a means of appeasement of the gods and atonement as well as to ward off future occurrences, the rites carried out in strict accordance with the form prescribed by relevant sacred authorities.

Of particular interest in this respect is the Roman historian, Titus Livius, generally known as Livy in English. He was born in Patavium (modern-day Padua), northern Italy, his life spanning the turbulent years of the end of the Republic and the first five decades of the Empire (c. 59 BC to 17 AD). His monumental history of the Roman state teems with accounts of extraordinary happenings, carefully registered and accurately, if summarily, identified.

Among the reports by Livy of alleged ominous portents, often enumerated are cases of hermaphroditism in men or animals. As previously mentioned, such cases typically aroused strong negative reactions among the people, who judged them to be 'monstrous abominations'. Public feeling thus condoned the harsh disposal of the ill-starred individuals, an act which was in later times a fixed component of the rites of placation and propitiation offered to hostile or offended cosmic powers.

We thus read in Livy's chronicles that in 209 BC a child was born at Sinuessa, "of ambiguous sex, between a male and a female, such as are commonly called androgynes, a term derived from the Greek language, which is better adapted, as for most other purposes, so for the composition of words" (Livy, XXVII, 11, 4-51). Similarly, in 206 BC "at Caere... a lamb had been yeaned which was both male and female" (Livy XXVIII, 11, 32). And in 200 BC, "Besides, monstrous births of animals [that] were reported to have occurred in many places, in the country of the Sabines, an infant was born whose sex was doubtful; and another was found, sixteen years old, of doubtful sex" (Livy XXXI, 12, 43). Since those irregularities pertaining to the matter of sex were especially discountenanced, the public regarding them as utter abominations, hermaphrodites were drowned in the sea, the element that was said to purify all enormities. ${ }^{4}$

Another instance of hermaphroditism, this of major medical interest, was reported by the same historian a few years earlier than the abovementioned case. In the year 207 BC Livy records a singularly remarkable sequence of fearful prodigies and among them the standard 'offense', a case of androgynism, but of a singular character. “... People's minds ... were again disturbed by intelligence that an infant had been born at Frusino [modern day Frusinoe of Lazio, a town of Latium located approx. $95 \mathrm{~km}$ from Rome and noted for its rocky landscape and the hardy character of its inhabitants (Silius Italicus, Punicorum, viii 398; xii 532)] as large as a child of four years old, and not so much an object of wonder from its size as that it was born formed in such a way that it was uncertain whether it was male or female, which was also the case two years before at Sinuessa" (Livy, XXVII, 37, 5).

\section{B. MEDICAL DIFFERENTIAL DIAGNOSIS}

Medical interpretation of the case described by Titus Livy suggests the differential diagnosis of the concurrent presence of macrosomia and ambiguous genitalia in neonates.

External genitalial ambiguity is the most prominent finding attested by the author in the described case. According to a recent study, ${ }^{6}$ neonates with body mass index $(\mathrm{BMI}) \geq 14.2 \mathrm{~kg} / \mathrm{m}^{2}$ are considered as macrosomic, as the evaluation of macrosomia depends not only on the body mass but on the birth length as well. The mean BMI of a four-year-old child is $17 \mathrm{~kg} / \mathrm{m}^{2}$ for males and $15.5 \mathrm{~kg} / \mathrm{m}^{2}$ for females. Consequently, a newborn demonstrating the size of a four-year-old child could be considered as a case of macrosomia. Taking into account that there is no obvious correlation between these clinical entities (macrosomia and genital ambiguity), the possibility of their non-coincidental concurrence may be derived only through rigorous review of their discrete pathophysiological pathways.

Ambiguous genitalia are a phenotype indicating underlying disorders of sex differentiation (DSD). DSD is classified as sex chromosome DSD, 46,XY DSD or 46,XX DSD. Disorders of gonadal development, inadequate biosynthesis and defective action of sex steroids are the underlying causes responsible for the vast majority of DSD. Inadequate biosynthesis of sex steroids can result from various enzymatic deficien- 
cies in the cascade of steroid synthesis. Defects in sex steroids action may be due to non-functional receptors, altering the responsiveness of the target-tissues to the sex steroids signal, thus leading to conditions of sex steroids insensitivity. Disorders of gonadal development include mutations in genes involved in early gonadal development, such as the steroidogenic factor 1 (SF-1) gene, dosage-sensitive sex reversal, adrenal hypoplasia critical region on chromosome X-1 (DAX1) gene, the Wilms Tumor 1 (WT1) gene and the wingless-related mouse mammary tumor virus integrated site 4 (WNT4) gene.

The WT1 gene encodes a transcription factor acting as a tumor suppressor protein, thus regulating growth and differentiation. Apart from its role in initiating or promoting Wilms tumor, WT1 regulates the development of both kidney and early gonad. ${ }^{7}$ WT1 and SF-1 act in a synergic manner towards the regression of the mullerian ducts in 46XY embryos by inducing expression of anti-mullerian hormone (AMH). Additionally, WT1 contributes to transcriptional activation of the SRY gene, which is responsible for male differentiation. ${ }^{8}$ On the other hand, WNT4 is essential for the formation of mullerian duct structures, for nephrogenesis as well as for the inhibition of genes encoding enzymes that are necessary for androgen synthesis. ${ }^{9}$ DAX1 appears to play a role in both ovarian and testicular development, since it has been suggested that in males it promotes spermatogenesis, whereas in females it mediates SRY inhibition..$^{10}$ Furthermore, the common embryologic origin of the genitourinary system could expand the phenotypic spectrum of the disorders involving gonadal impairment. Two distinct syndromes have been described confirming the latter. Mayer-Rokitansky-Kuster-Hauser syndrome, which has mainly been associated with WNT4 mutations, is characterized by congenital aplasia of the uterus and the upper $2 / 3$ of the vagina and is frequently ( $40 \%$ of cases) accompanied by malformations of the urinary tract. ${ }^{9}$ Kallmann syndrome, the cardinal features of which are hypogonadotropic hypogonadism and anosmia, is associated with renal agenesis, though not accompanied by genitalia malformation. ${ }^{11}$ The genetic link in these cases is the KAL1 gene which is identified both in the olfactory placode, facilitating the migration of the GnRH neurons to the hypothalamus, and in metanephros.
Different mutations by converging on a loss of function of WT1 protein isoforms result in a spectrum of disorders, namely Frasier, Denys-Drash and WAGR syndromes, commonly characterized by renal disease, intersex and predisposition to tumorigenesis. ${ }^{12}$ As for genital abnormalities, sexes are not similarly affected. Although 46XY fetuses appear to be male pseudohermaphrodites exhibiting ambiguous genitalia, 46XX fetuses usually appear with a normal phenotype but occasionally with streak gonads. ${ }^{13}$ Dysgenetic testes is the cardinal feature of Denys-Drash syndrome, which results in sexual ambiguity with chronic renal disease due to diffuse mesangial sclerosis as well as high incidence of Wilms tumor completing the 'mosaic' of the phenotype. A phenotypic variant includes dysgenetic gonads leading to male-to-female sex reversal in 46XY males and pubertal delay in both sexes as encountered in Frasier syndrome, additionally characterized by both chronic renal disease due to nephrotic syndrome and focal segmental glomerulosclerosis and high incidence of gonadoblastoma. Finally, WAGR syndrome is characterized by Wilms tumor, aniridia, genitourinary malformations and mental retardation. ${ }^{12}$ However, macrosomia is not a component of any of the aforementioned syndromes.

During gestation, maternal pituitary growth hormone $(\mathrm{GH})$, which exerts a somatogenic effect on the fetus, is progressively replaced by placental $\mathrm{GH}$ (pGH) in the serum of the pregnant woman after the second half of gestation. ${ }^{14} \mathrm{pGH}$ is a cardinal regulator of maternal insulin-like growth factor I (IGF-I) ${ }^{15} \mathrm{It}$ has been shown that as GH is not able to cross the placenta; ${ }^{16}$ it is highly likely that its growing effects are mediated by alterations in maternal IGF-I levels. Furthermore, IGF-I is significantly correlated with IGF-II throughout pregnancy. ${ }^{17}$ Additionally, in a study determining the variants of birth weight, ${ }^{18}$ it has been shown that maternal GH-related parameters, such as IGF-I, IGF-II, IGF binding proteins 1 and 3 (IGFBP-1, IGFBP-3), PGH, free $\mathrm{pGH}$ and $\mathrm{GH}$ binding protein (GHBP), are responsible for up to $40 \%$ of the variance of birth weight. Consequently, as IGF-I and IGF-II both play a central role in fetal growth, it seems plausible that IGF-I and IGF-II functional or biosynthesis disorders could lead to macrosomia.

Most of the biological actions of IGF-I and IGF-II are mediated by the IGF-I receptor, which is associ- 
ated with ras/raf-MAPK and phosphatidylinositol 3-kinase signalling cascades. In vitro studies have confirmed the unequivocal correlation between IGF-I receptor and WT1, suggesting that expression of each splice variant of the WT1 protein likely suppresses IGF-I receptor promoter activity to a different extent. ${ }^{19,20}$

As already mentioned, mutations of WT1 gene may result in genital ambiguity by affecting the expression of sex determining genes (in 46XY fetuses). Moreover, as WT1 gene expression is implicated in altered IGF-I and IGF-II activity, mutations of the gene may lead to overgrowth during fetal life. Therefore, fetal macrosomia and ambiguous genitalia could be concomitant findings of WT1 related disorders (affecting 46XY fetuses).

Besides macrosomia due to diabetic pregnancy, certain other fetal overgrowth syndromes have been described in the literature. ${ }^{21,22}$ Among the numerous overgrowth syndromes exhibiting significant clinical overlap, only in Beckwith-Wiedemann and SimpsonGolabi-Behmel syndromes are macrosomia and sexual ambiguity both included in the phenotype.

Beckwith-Wiedemann syndrome is characterized by macrosomia, macroglossia, visceromegaly, embryonal tumors, omphalocele, neonatal hypoglycemia, ear creases/pits, adrenocortical cytomegaly and genitourinary malformations (clitoromegaly, hypospadias and cryptorchidism). ${ }^{21,22}$ Beckwith-Wiedemann syndrome is associated with abnormal regulation of gene transcription by any one of a number of mechanisms in an imprinted domain on chromosome 11p15.5 leading to up-regulation of IGF-II expression, which is encoded by the imprinted IGF-II gene. Loss of imprinting is responsible for biallelic expression of the IGF-II gene, leading to IGF-II overexpression. On the other hand, unlike the IGF-I receptor, which mediates IGF-II effect, the IGF-II receptor functions by degradating IGF-II excess. Thus, a mutant IGF-II receptor gene, which is maternally inherited, leads to increased serum levels of IGF-II, expanding the genetic substratum of the syndrome. ${ }^{23}$ Furthermore, congenital urinary malformations might entail genital abnormalities, given the common embryological origin of urinary and genital systems. In 46XY fetuses differentiation, mitogenesis and steroidogenesis of
Leydig cells - the testosterone-producing cells - are significantly regulated by the IGF system, ${ }^{24}$ implying a possible IGF mediated abnormality of genitalial appearance. In the literature, no case of true ambiguous genitalia in Beckwith-Wiedemann syndrome has ever been described.

Simpson-Golabi-Behmel syndrome is indirectly associated with IGF-II. It is an X-linked disorder caused by mutations in GPC3 gene which encodes glypican-3, a cell-surface heparin sulfate proteoglycan that contributes to down-regulation of IGF-II. Studies investigating the expression pattern of GPC3 using immunohistochemistry methods revealed that GPC3 expression in different embryonic tissues varies throughout gestation. As for the genital system, a sexspecific as well as a stage-specific GPC3 expression was observed. Specifically, there was feeble GPC3 expression recorded during the first half of gestation. However, in later stages, GPC3 expression was noted in males but not in females. ${ }^{25}$ Simpson-GolabiBehmel syndrome is characterized by macrosomia, characteristic facial features (macrocephaly, ocular hypertelorism, epicanthal folds and downslanting palpebral fissures, macrostomia, macroglossia, cleft lip and/or submucous cleft palate with a bifid uvula, high and narrow palate), multiple congenital anomalies (congenital heart disease, supernumerary nipples, diastasis recti/umbilical hernia, diaphragmatic hernia, renal dysplasia/nephromegaly, hypospadias, bifid scrotum, cryptorchidism, hydrocele and inguinal hernia) and increased predisposition tumors. ${ }^{21}$ Therefore, fetal macrosomia and ambiguous genitalia could be concomitant findings of Simpson-Golabi-Behmel syndrome affecting 46XY fetuses.

As for the case under review, fetal overgrowth syndromes are less likely diagnoses given that the fetuses affected usually exhibit distinct phenotypic features, which are not attested by the author. Moreover, although cases of mild sexual ambiguity could lead to problems of sexual assignment, no instance of true ambiguous genitalia has ever been described in fetal overgrowth syndromes.

Various cortisol production disorders, resulting in androgen but not glucocorticoid excess, are associated with external genitalial ambiguity. Hypothalamicpituitary-adrenal axis activation results in androgen 
excess conditions, leading to virilization of female fetuses that exhibit ambiguous genitalia with clitoral enlargement, fusion of the labial folds and rostral migration of the urethral/vaginal perineal orifice. ${ }^{26}$ Although androgens accelerate growth and bone maturation in children, it seems that alterations in androgen signalling have little impact on birth weight. ${ }^{27}$

Normal fetal growth depends on placental metabolism and maternal substrate supply. Various growth factors, including cortisol as well as thyroid hormones, are implicated in fetal growth. Glucocorticoids increase circulating glucose levels via increased glucose production or decreased peripheral glucose uptake through inhibition of insulin release from $\beta$ pancreatic cells. ${ }^{28}$ Nevertheless, elevated circulating glucose levels are finally outweighed by increased insulin secretion, resulting in hyperinsulinemia and insulin resistance. It is well known that hyperinsulinemia is a principal determinant of IGF-I levels, ${ }^{25}$ which is thought to be responsible for fetal macrosomia. Therefore, disorders leading to cortisol overproduction could be a possible causative factor of macrosomia.

A probable cause of abnormal glucocorticoid synthesis leading to glucocorticoid and androgen excess could be a defect in the glucocorticoid receptor gene leading to glucocorticoid resistance. Abolishment of cortisol-mediated negative feedback leads to inappropriate activation of the hypothalamic-pituitaryadrenal axis, resulting in an increase in both ACTH and cortisol levels accompanied by increased mineralocorticoid activity (due to overproduced cortisol, deoxycorticosterone and corticosterone), as well as androgen excess (due to overproduction of androstenedione, dehydroepiandrosterone and DHEAS), leading to ambiguous genitalia phenotype at birth in females and later on to signs of androgen and mineralocorticoid excess in both sexes. ${ }^{29,30}$ However, no positive effects on fetal growth have ever been reported. The reason for this discrepancy lies in fetal adrenal cortex physiology.

The fetal adrenal cortex has a dual role during gestation. First of all, it is part of the fetoplacental unit which, after 8 weeks of gestation, is the major contributor to the production of estradiol essential for maintenance of pregnancy. The cascade of estradiol biosynthesis initiates, together with DHEAS, production by the fetal adrenal cortex. DHEAS is successively converted to DHEA, androstenedione, estrone and estradiol in the placenta. Despite the large amounts of DHEAS produced, fetal adrenal cortex cortisol biosynthesis and subsequent suppression of the hypothalamic-pituitary-adrenal axis during the 7th-10th week of gestation protect female fetuses from virilization ${ }^{31}$ by preventing androgen excess during the critical period of sexual differentiation that occurs during this 3-week period. Estradiol production is taken over by placental aromatase which is expressed later in pregnancy. ${ }^{32}$ It has been suggested that the fetal adrenal cortex does not produce cortisol throughout pregnancy but only before the 10th week and in late gestation, normally being in a state of inactivation. $3 \beta \mathrm{HSD}$, the enzyme converting pregnenolone to progesterone, is detected only in late pregnancy, suggesting that de novo synthesis of cortisol is unattainable in earlier developmental stages.

Consequently, unlike androgen excess effect, any defected cortisol effect related to growth cannot be obvious before birth. Therefore macrosomia and ambiguous genitalia are extremely unlikely to be attributable to a generalized glucocorticoid resistance in a $46 \mathrm{XX}$ fetus.

In conclusion, female pseudohermaphroditism should be excluded from the differential diagnosis of the neonate exhibiting macrosomia and ambiguous genitalia, since it is more likely to be a case of $46 \mathrm{XY}$ disorder of sexual differentiation. However, in this instance we are not able to distinguish between WT1 related disorders and fetal overgrowth syndromes given the data at present available. Thus, more than 2300 years after the citizens of Frusino experienced intense bewilderment over the sex of this anomalous neonate, an answer to resolve their puzzlement is today possible, namely that the newborn was indeed a boy, a 46XY male pseudohermaphroditism most likely due to a mutation in WT1 gene.

\section{REFERENCES}

1. Livy XXVII, 11, 4-5: “Et... satis constabat ... et Sinuesse natum ambiguo inter narem ac feminam sexu infantem, quos androgynos volgus, ut pleraque, faciliore ad duplicanda verba Graeco sermone appellat".

2. Livy XXVIII, 11, 3: "Caere... et agnus mas idem feminaque natus erat”. 
3. Livy XXXI, 12, 4: "Iam animalium obscoeni foetus pluribus locis nuntiabantur. In Sabinis incertus infans natus, masculus an femina esset; alter sexdecim iam annorum item ambiguo sexu inventus".

4. Livy XXI, 12, 4. Livy explains: "All these were considered as horrid and deformed, and as if nature were straying to strange productions. Above all, the half-males were particularly abominated, and they were ordered to be immediately thrown into the sea, as had been lately done with a production of the same monstrous kind, in the consulate of Caius Claudius and Marcus Livius". ["Foeda omnia et deformia, errantisque in alienos foetus naturae visa. Ante omnia abominati semimares, iussique in mare extemplo deportati; sicut proxime, C. Claudio, M. Livio consulibus, deportatus similis prodigii foetus erat"]. Livy then goes on to relate the expiations, supplications and litanies that were subsequently officially performed in order to cure the body-politic from the molestation of such sex abnormalities.

5. Livy, XXVII, 37, 5: "Liberatas religione mentes turbavit rursus nuntiatum Frusimone natum esse infantem quadrimo parem nec magnitudine tam mirandum quam quod is quoque, ut Sinuessae biennio ante, incertus mas an femina esset natus erat". - What was done about it is related in detail by Livy: "Aruspices, called in from Etruria, declared this to be indeed a foul and perverted prodigy, which ought to be removed out of the Roman territory, and, being kept far from coming into contact with the earth, to be plunged into the deep. They shut it up alive in a chest, and carrying it away, threw it into the sea. The Pontiffs also decreed that thrice nine virgins should go through the city singing a hymn. While in the temple of Jupiter Stator they were learning this hymn, which was composed by the poet Livius, etc." (For there occurred further ominous events and the rites of appeasement were in consequence still more complicated to correspond to the exigencies of these events, but also in response to a formidable danger for the State). Livy XXVII, 37, 6-7: ["Id vero haruspices ex Etruria acciti foedum ac turpe prodigium dicere; extorrem agro Romano, procul terrae contactu, alto mergendum. Vivum in arcam condidere proventunque in mare proiecerunt. Decrevere item pontifices ut virgines ter novena per urbem euntes carmen canerent. Id cum in Iovis Statoris aede discerent conditum ab Livio poeta carmen etc. "]. The litany of the virgins singing the hymn of Livius is described in the sequel loc.cit. $\$$ 11-15. (Cf. Festus, de Verborum Significatione, s.v. scribas).

6. Liu XX, Song WW, Liu HB, 2010, Evaluation the significance of body mass index in diagnosing macrosomia in human neonate. Zhonghua Fu Chan Ke Za Zhi Jul; 45: 488-489

7. Pritchard-Jones K, Fleming S, Davidson D, et al, 1990 The candidate Wilms' tumour gene is involved in genitourinary development. Nature 346: 194-197.

8. Hossain A, Saunders GF, 2001. The human sex-deter- mining gene SRY is a direct target of WT1. J Biol Chem 276: 16817-16823.

9. Morcel K, Camborieux L; Programme de Recherches sur les Aplasies Müllériennes, Guerrier D, 2007. MayerRokitansky-Küster-Hauser (MRKH) syndrome. Orphanet J Rare Dis 14; 2:13. Review.

10. Kousta E, Papathanasiou A, Skordis N, 2010, Sex determination and disorders of sex development according to the revised nomenclature and classification in 46, XX individuals. Hormones (Athens) 9: 218-131.

11. Georgopoulos NA, Koika V, Galli-Tsinopoulou A, et al, 2007 Renal dysgenesis and KAL1 gene defects in patients with sporadic Kallmann syndrome. Fertil Steril 88: 1311-1317.

12. Andrade JG, Guaragna MS, Soardi FC, Guerra-Junior G, Mello MP, Maciel-Guerra AT, 2008 Clinical and genetic findings of five patients with WT1-related disorders. Arq Bras Endocrinol Metab 52: 1236-1243.

13. Koziell A, Grundy R, 1999 Frasier and Denys-Drash syndromes: different disorders or part of a spectrum? Arch Dis Child 81: 365-369.

14. Frankenne F, Closset J, Gomez F, Scippo ML, Smal J, Hennen G, 1988 The physiology of growth hormones (GHs) in pregnant women and partial characterization of the placental GH variant. J Clin Endocrinol Metab 66: 1171-1180.

15. Caufriez A, Frankenne F, Englert Y, et al, 1990 Placental growth hormone as a potential regulator of maternal IGF-I during human pregnancy. Am J Physiol 258: E1014-E1019.

16. Fholenhag KI, Sandstrom IM, Malmlof K, Skottner AI, Nyberg FJ, 1994 Human growth hormone does not cross the placenta of the pregnant rat. Growth Regul 4: 181-187.

17. Lauszus FF, Klebe JG, Flyvbjerg A, 2001 Macrosomia associated with maternal serum insulin-like growth factor-I and -II in diabetic pregnancy. Obstet Gynecol 97(5 Pt 1): 734-741.

18. McIntyre HD, Serek R, Crane DI, et al, 2000 Placental Growth Hormone (GH), GH-Binding Protein, and Insulin-Like Growth Factor Axis in Normal, GrowthRetarded, and Diabetic Pregnancies: Correlations with Fetal Growth. J Clin Endocrinol Metab 85: 1143-1150.

19. Werner H, Rauscher III FJ, Sukhatme VP, Drummond IA, Roberts Jr CT, LeRoith D, 1994 Transcriptional repression of the insulin-like growth factor I receptor (IGF-I-R) gene by the tumor suppressor WT1 involves binding to sequences both upstream and downstream of the IGF-I-R gene transcription start site. J Biol Chem 269: 12577-12582.

20. Werner H, Shen-Orr Z, Rauscher III FJ, Morris JF, Roberts Jr CT, LeRoith D, 1995 Inhibition of cellular proliferation by the Wilms' tumor suppressor WT1 is associated with suppression of insulin-like growth factor I receptor gene expression. Mol Cell Biol 15: 3516-3522. 
21. James A, Culver K, Golabi M, 1993-2006 SimpsonGolabi-Behmel Syndrome. In: Pagon RA, Bird TC, Dolan CR, Stephens K, editors. GeneReviews [Internet]. Seattle (WA): University of Washington, Seattle.

22. Wong Charlene A, Cuda S, Kirsch, 2011 A review of the urologic manifestations of Beckwith-Wiedemann syndrome. J Pediatr Urol 7: 140-144.

23. Colón E, Zaman F, Axelson M, et al, 2007 Insulin-Like Growth Factor-I Is an Important Antiapoptotic Factor for Rat Leydig Cells during Postnatal Development. Endocrinology 148: 128-139.

24. Weksberg R, Shuman C, Beckwith JB, 2010 BeckwithWiedemann syndrome. Eur J Hum Genet 18: 8-14.

25. Iglesias BV, Centeno G, Pascuccelli H, et al, 2008 Expression pattern of glypican-3 (GPC3) during human embryonic and fetal development. Histol Histopathol 23: 1333-1340.

26. White PC, Speiser PW, 2000 Congenital Adrenal Hyperplasia due to 21-Hydroxylase Deficiency. Endocr Rev 21: 245-291.

27. Miles HL, Gidlöf S, Nordenström A, Ong KK, Hughes
IA, 2010 The role of androgens in fetal growth: observational study in two genetic models of disordered androgen signalling. Arch Dis Child Fetal Neonatal Ed 95: F435-438.

28. Patel R, Patel M, Tsai R, et al, 2011 LXR $\beta$ is required for glucocorticoid-induced hyperglycemia and hepatosteatosis in mice. J Clin Invest 121: 431-441. doi: 10.1172/JCI41681.

29. Charmandari E, Kino T, Ichijo T, Chrousos GP, 2008 Generalized glucocorticoid resistance: clinical aspects, molecular mechanisms, and implications of a rare genetic disorder. J Clin Endocrinol Metab 93: 1563-1572.

30. Mendonca BB, Leite MV, de Castro M, et al, 2002 Female Pseudohermaphroditism Caused by a Novel Homozygous Missense Mutation of the GR Gene. J Clin Endocrinol Metab 87: 1805-1809.

31. Mesiano S, Jaffe RB, 1997 Developmental and functional biology of the primate fetal adrenal cortex. Endocr Rev 18: 378-403.

32. White PC, 2006. Ontogeny of adrenal steroid biosynthesis: why girls will be girls. J Clin Invest 116: 872-874. 